\title{
Exploring the use of large sporting events in the post-crash, post-welfare city: a 'legacy' of increasing insecurity?
}

\section{Gerry Mooney}

The Open University, Scotland

\section{Vikki McCall}

University of Stirling, Scotland

\section{Kirsteen Paton}

University of Leeds, England

\section{Abstract}

Large scale sporting events are a major part of urban policy and regeneration strategies in the UK and globally. These events court as much controversy and criticism from academics and community groups as they are coveted by local and national governments. While they claim to have lasting long-term benefits for the host cities, neighbourhoods and ergo residents, evidence shows that effects are often scant, oblique or, conversely, negative. This has new significance in the context of austerity. This paper offers original empirical evidence of the experiences surrounding the Glasgow Commonwealth Games 2014. A series of diaries and focus groups with those living and working in the East End of Glasgow revealed hope of a positive impact on the East End, but this coincided with anxiety and feelings of exclusion around the Commonwealth Games 2014. It explores the current form that urban social policy takes in the post-crash, post welfare context, as exemplified by the Commonwealth Games. The paper goes on to raise questions about the real winners of large sporting events.

Keywords

Commonwealth Games 2014, Glasgow, urban policy, welfare, austerity, insecurity

\section{Introduction}

The Glasgow Commonwealth Games 2014 (CWG) were set to be a catalyst for regeneration, investment, and legacy to impact and improve the lives of the people in the East End of Glasgow. The CWG, however, took place in a context of post-financial crisis, increasing inequality, welfare conditionality and dwindling welfare provision throughout the UK. (Hills, 2015; Lansley and Mack, 2015; McKendrick et al, 2014) Such welfare reforms are being implemented by the Coalition Government as part of a wider programme austerity. (see O'Hara, 2014). The freeze in council taxes in Scotland by the Scottish Government is also diminishing the ability of local authorities to provide additional funding for the kinds of services that might work to reduce the impact of UK Government policies. Taken together, are having a hugely negative impact on the lives of millions of individuals, families and communities across the UK. Arguably their greatest and most visible impacts are on disadvantaged working class communities in the mainly ex-industrial areas of cities wherein a large proportion of the population are reliant on some form of state provided welfare. These are also often cities which have seen disinvestment, have a considerable proportion of its working 
population employed by the state, in jobs which are also subjected to large-scale redundancies and downward pressures on wages and cuts in benefits, pensions and other social and economic entitlements.

As a city that has long topped UK tables in relation to poverty, disadvantage and other social ills, Glasgow represents a valuable illustrative case study to explore not only the ways in which large-scale 'flagship' events are tied to policy processes of urban renewal and regeneration, but also to wider strategies of welfare reform. Yet, it is argued that such events tend to be viewed in isolation from social welfare strategies. The 2014 Commonwealth Games in Glasgow took place in one of the most deprived parts of the UK, and was tasked not only with economic but important social goals - or 'legacies' to use the language deployed by the promoters of flagship events - which suggest we need to explore the relationship between such events and the impacts of wider government policies in disadvantaged areas delivered in an post-crash, 'post-welfare' (O'Connor, 2000) era of austerity. As we progress to focus on Glasgow, then, the interconnections between shifts in welfare policies, the impacts of austerity and large flagship events in disadvantaged localities will occupy centre stage.

The East End of Glasgow, long identified by politicians, policy makers, the media and other outsiders as a 'place of blemish.' (Wacquant, 2007: 67) This part of Glasgow is where a number of the Commonwealth Games venues, including the Athletes' Village, are located. The overwhelmingly negative and stereotypical image of the East End projected from the outside plays a significant part in the identification of the East End as being 'ripe' for various forms of intervention by the local authorities and other agencies, that it requires to be 'remade'. This is also an internal process that is reflected in a myriad of micro-geographies that locals use in their mental mapping of the area, which also reminds us that the area is far from being an homogenous district. Remaking an area, however, is also largely about attempting to remake the population of an area. The East End of Glasgow has often been subjected to a range of negative discourses that support individualistic notions of poverty. It is viewed as symptomatic of a 'broken society', cut-adrift from 'mainstream' society and the generators of economic health located elsewhere. (Gray and Mooney, 2011; Mooney and Danson, 1997; Mooney, 2009) As such, it has been the target of numerous regeneration programmes, not least during the 1970s with the Glasgow Eastern Area Renewal (GEAR) project, described as Scotland's version of the 1977 English 'inner cities' programme. (Donnison and Middleton, 1987; Lever and Moore, 1986) The Commonwealth Games represented the latest in a long line of state interventions in the East End. In turn it has been viewed by policy makers a strategically important stepping stone for a multitude of regeneration activities that have been positioned as a means of remaking the area and its population, to 'strengthen and empower' the communities of the East End. 
There is a need for the significance and impacts of these events to be critically appraised within a changing political, economic and welfare context. This includes the concept and process of austerity, and welfare 'reforms', increasing conditionality and large-scale cuts in public service provision and employment which is impacting on the most disadvantaged populations of many UK cities today. These issues are explored by offering empirical evidence from a wider-research project: 'Beyond stigma: exploring the everyday lives of the people living in the East End of Glasgow', which aimed to compare the narratives surrounding the East End of Glasgow with the perspectives of those who live there. This research was conducted between May and October 2014. We asked residents to keep diaries during this period to record their experiences not only of the CWG but of life of an East End resident, living in austerity Britain; post-crash and post-welfare times. Diaries, along with repeated focus groups, provided a means of exploring the way the CWG were experienced by local residents allowing for reflexivity providing insight into their daily lives and thoughts. This offered an opportunity to explore the dissonance between the event and everyday lives but served to challenge stigmatising myths. In this paper we draw from some of our findings which are a characterised by residents experience of insecurity in relation to the Games and a changing welfare landscape. Urban social policy vis-à-vis the Games, delivered a time of austerity, not only reduces spending on social security, it actively increase social and economic insecurity.

\section{Urban social policy in Glasgow and the UK as an anti-welfare strategy}

Glasgow of course is not the first city to hold a large sporting event (as opposed to global 'mega' events such as the 2012 London Olympic Games) and it is certainly not the first city wherein great claims were made that the 'legacy' of the Games would be evidenced by the large-scale regeneration of a long neglected and disadvantaged locality. The transformative visions of the 2002 Commonwealth Games in Manchester, for example, has been well documented with the Manchester Games tied to other urban 'boosterist' and growth strategies which promised a revitalised future for a city where post-1960s deindustrialisation had replaced earlier times of manufacturing growth and relative prosperity (Cochrane et al, 1996; Ward, 2003). From the 1970s and 1980s, most ex-industrial cities in the UK have been places of relative economic decline, much of it on the back of state sponsored disinvestment from industries and areas on the back of significant political shifts in the policies and strategies of the UK state. The rise of mass unemployment in many urban areas during the 1980s was part and parcel of successive Conservative Government strategies (and which were largely followed by New Labour) to reshape the city, opening-it up for private sector investment and gain - fuelled by cheapening labour costs and by cuts in social provisions and by the gradual, though never completed, withdrawal of the state from large-scale provision in the area of housing and other public service provision. 
The changing economic, social, political and geographical relations of the 1970s and 1980s had a disproportionate weight on the working class of the older urban areas (Friend and Metcalf, 1981: 22), as have subsequent periods of economic change. As such urban policy often responded to industry related issues and its response was spatial: demolition, wholesale moves of communities and so on. Taken together these political, economic and social changes in the urban setting have left some areas, and the people who live there, as in some ways 'cut-off' from economic growth and otherwise successful programmes of city renewal. Glasgow arguably represents the best example of such and the 'Glasgow model' of urban regeneration is widely proclaimed as offering a vision to other cities across Europe (Gray and Mooney, 2011; Mooney, 2004), based on regeneration from the 1990 European Capital of Culture.

For those 'left-behind' in places typified by Glasgow's East End, in comparison with the apparently successful 'transformation' of other parts of Glasgow, territorial stigmatisation compounds what Loïc Wacquant has termed the 'advanced marginality' that characterises many of the most impoverished and disadvantaged areas of the post-industrial city. (Wacquant, 2008) What we see happening in Glasgow today, as well as in numerous other urban locales across the UK in the recent past, are growing levels of disadvantage areas attempting to undergo major changes in the urban landscape accompanied by far reaching welfare reform programmes. What is significant about the Glasgow CWG is that through viewing it we can chart an evolution in urban social policy in the UK in the post-crash, post welfare context, which combines ideas of area and individual social pathology with market dogma in important ways.

The enduring legacies of 1970s-2000s neoliberalism is now accompanied by an economic context that is market driven and sees private sector investment and state deregulation and disinvestment, except where it generates private sector activity, as the main generators of urban economic success. Pre-mid 1990s urban interventions were primarily concerned with market led renewal of the urban fabric. New Labour, in the late 1990s, put greater emphasis on the social dimensions of urban change and the role of community in participating as active partners in these processes. Today that agenda looks more strongly like a strategy of devolving responsibility to communities and individuals with a correlating range of austerity measures that are reducing public spending levels well below those of the 1970s-mid 2000s (and in some accounts reducing it to levels not seen since the inter-war period in the 1930s, see Wintour and Elliot, 2014) - and by yet another, yet more virulent and even more punitive phase of welfare reform, which is having a hugely negative impact on some of the most disadvantaged populations and places in the contemporary UK.

What passes for 'urban social policy' in Scotland (or indeed the UK) in the second decade of the $21^{\text {st }}$ century, compounds ambiguities as to the definition, meaning and aims of urban 
social policy, and its specification of causality or 'urban problems' and prescription of the solution. In urban social policy the 'problem definition' begins with the area (Cochrane, 2007: 3) and by extension the people resident in that place. Urban social policies are aimed at local scale intervention into socio-economic issues which are deemed as acute and which cannot be attended to by national state social security measures. The consequences of this, argues Cochrane, are 'the identification of the 'entrepreneurial' or the 'competitive city'... that sees economic success as the necessary precondition for the well-being (or welfare) of citizens rather than the existence of an extensive (or socially democratic) welfare state'. (Cochrane, 2007: 11)

The policy discourse surrounding the 2014 Glasgow Commonwealth Games mirrors the causal assumption between (private sector) economic investment and the increasing 'wellbeing' (itself a vague and contested notion) of particular social groups and places. The CWG 2014 had an explicit focus of being a mechanism for economy investment and regeneration in Glasgow, specifically the East End. In an official evaluation of the baseline for the CWG the Scottish Government stated that:

But there are also plans to affect social outcomes for the city, using the Glasgow 2014 Games as an impetus for raising aspirations, driving achievement and contributing to a positive future for Glasgow. Notably, there has been substantial new investment for the Games in Glasgow's east end, in some of the most deprived communities in Scotland. The Games investment has become integral to plans for a wider, long-term regeneration initiative being led by the Clyde Gateway Urban Regeneration Company (URC). Significant improvements have been made to the transport infrastructure in the surrounding area, including the M74 improvements and the new Clyde Gateway route. (Scottish Government Social Research, 2012: 7)

Therefore the underpinning approach to the social issues in Glasgow's East End is embedded in an economic framework, mirroring the neo-liberal approach that economic prosperity determines social welfare. Cochrane (2007) argues many problems in a city are linked strongly with the problem of economic decline. This is reinforced by the overall Scottish Government's National Performance Framework that integrates all policy expectations and outcomes to the purpose of economic growth. (Scottish Government, 2007) Therefore, investment in large sporting events (such as the Olympics and Commonwealth Games) are considered "the holy grail" or urban cultural policy (Cochrane, 2007: 117), fundamental to pushing already planned infrastructure changes and regeneration strategies (such as the Clyde Gateway in Glasgow and the Thames Gateway in London). The 2014 Commonwealth Games became identified as a way of attracting other private-led investment while also allowing the city further opportunity to be marketed and rebranded, this time on an 
international stage. This ultimately opens a space for private developers to cash in on state investment to subsidise developments, many of which may have been in the pipeline. This agenda has renewed meaning in the post-crash context. While urban development and the real estate market contributed to the bubble which precipitated the financial crash in 2008, pursuit of profit here has not been hampered as illustrated by the Games related activities and investment. In fact is seems to be pursued more fervently. Not only are the problems of land commodification cautioned from the events around the crisis, the efficacy of market led, 'trickle-down' renewal is questionable.

What is observable is an evolution of urban social policy towards both a market dogma and social pathology. The devolving of responsibility and power from national governments (here understood as Scottish and/or UK) to cities and regions sees local authorities charged with income-generation obligations. Cochrane (2007: 91) further links this to "the city-based campaigns for the winning of mega events, such as the Olympics, [which] can be seen as prime examples of urban entrepreneurialism". This levers public and private support in the form of 'grantmanship' and is constructed as a local initiative, while being subsidised also by national governments and wider sources. This approach reduces the role of the 'community' as a 'significant agent' in shaping the future of their urban spaces which had been a key element in New Labour's brand of urban regeneration, 'urban renaissance'. The renewed emphasis on economic success has fundamental impacts on limiting the attention on the actual people in the areas that need support, which has more significance given the impact of austerity measures and welfare reform. Understanding the impact of the CWG not only requires acknowledging the meaning of the post-crash financial context but of austerity and the post-welfare landscape.

\section{The changing welfare landscape of Glasgow}

The role of the 2014 CWG in Glasgow was tied to other strategies for urban renewal in the East End of the city in particular. As we have also argued, it is linked in other ways to attempted transformations in the populations of the East End, all too often depicted as a homogenous group of welfare dependents living lives that can no longer be sustained in the midst of economic decline by large-scale state transfers. The welfare landscape of Glasgow is part and parcel of the wider context that surrounds the CWG. Arguably, the most important aspects are contexts of welfare provision, marked by increasing conditionality and wider policy regulation of those who are state dependent. This also necessitates far-reaching ground level interventions in individual and family life of kinds that are often hugely invasive.

Welfare reforms are an integral part of the assault on state provision launched by the 2010 UK Coalition Government, legitimated in no small part by claims that the country can no longer afford such provision on a scale that has been in place in the recent past. 'Austerity' measures including wide-ranging cuts in public spending, public services, public sector wages 
and pensions, and other welfare benefits are presented as the only way to economic health. That such cuts impact on those who are among the most disadvantaged almost goes without saying. (Asenova et al, 2015; O'Hara, 2015) Today it is also accompanied by a culture of 'benefit bashing' that reflects a continuing tradition of blaming the most disadvantaged for their predicament. This is epitomised by lan Duncan Smith's 'Shettleston Man'. Taking its name from the Shettleston area in the East End of Glasgow, this is a welfare subject who 'lives in social housing and is terminally unemployed' and 'personifies a lost generation.' (BBC News, 2008; Mooney, 2009) There seems an endless supply of shock stories and programmes about 'welfare scroungers', which are further exploited by think tanks and politicians for political capital. (Crossley and Slater, 2014) These work to legitimate UK Government welfare reforms and play a role promoting ignorance on the structural causes of poverty. (Slater, 2012)

Austerity measures not only reduce spending on social security, they actively increase social insecurity. UK Government policies have worked to dumb down expectations of a secure working life, promising a future of hardship and insecurity, accompanied by personal and familial risk and uncertainty and these may also have detrimental health outcomes for working age people in receipt of benefits as well as their families, a particular issue in Glasgow where life expectancy and morbidity levels are already the worst in Western Europe. (McCartney, et al, 2012)

The state is arguably more active in places such as the East End of Glasgow than at any time in the recent past. Such interventions are driven by welfare reform strategies and often punitive work activation programmes that seek to promote employment as the only solution to long-term social and economic problems in the area. For the UK Government, politicians and policy makers the focus is therefore on welfare 'dependency' and in particular in worklessness (and other dysfunctional cultures that contribute to welfare dependency). These contribute to negative stigmatisations of the East End as a 'broken society' or a 'welfare ghetto.' (Mooney, 2009; Hancock and Mooney, 2013; Slater, 2014) State interventions of this kind seek to 'civilise' the population through the management and disciplining of the recalcitrant.

As Gray and Mooney (2013:10) have argued, there is another important dimension to these strategies and goals, albeit a related one:

...the political construction of place can act as a neo-liberal alibi for accumulation strategies led by the owners and managers of private capital. Meanwhile, the construction of place through territorial stigmatisation tends to obfuscate fundamental structural and functional differences underlying neighbourhood effects, and displaces 
questions of culpability and collective responsibility away from the state and business sectors.

From this point, it must be noted, problems in a specific area come to be identified as the problems of that area is not a new phenomenon. Likewise, the shortcomings of an 'area effects' approach has been long documented. (see Slater, 2015) 'Area effects' amount to more than a crude form of environmental and geographical determinism, whereby a place and its people are seen as the source of problems rather than structural inequalities. This is evident too in stigmatising discourses, which have an integral role to play in securing an area for state interventions. The East End of Glasgow is such a place and large scale events such as the 2014 CWG are part of 'recapturing' and 'securing' the area as a place that will attract inward (private) investment and opportunities for profits. This is on the back of speculative land and property deals and a population made available for low wage and casualised forms of employment of the most insecure and vulnerable kinds. (Gray and Mooney, 2011; McKendrick et al, 2014) All this is framed in a discourse that any changes are for the 'public good' and events such as the Commonwealth Games can become tools of government to suspend normal rules, rights and practices. (Porter and Gray, 2015)

Cochrane (2007: 138-139) notes that large scale events have been part of the process of redefining 'welfare' and urban policy has been part of a broader shift in the restructuring of welfare states. Cochrane does not, however, go on to describe this process as an exponentially punitive process. As a welfare strategy, large 'flagship' events such as the Games are clearly limited as a process of providing social security. The findings suggest that - in the post welfare context - the Games actually compound social insecurity. Our findings suggest this was a process that increased feelings of insecurity and therefore both reflects the impact of the punitivism of current welfare reforms and workfare schemes.

\section{Methodology}

The project from which this paper emerges aimed to explore the everyday lives of people living and working in Glasgow's East End. The project was influenced strongly by the concept of territorial stigmatisation and its focus on social, symbolic and physical space and its role in creating and continuing the process of marginalising certain communities. (Wacquant, 2008; Wacquant et al, 2014) 50 people were involved in the project, with 22 participants submitting diaries over the period of June, July, August and September 2014 to help capture their everyday experiences of life in the East End and their reflections on the Games (which took place between July 23 and August 3). The diaries were supplemented by five focus groups with a cohort of diary participants, held before, during and following the CWG (the final one in October 2014). The research also included a further two focus groups with non-diary participants to capture other experiences. What was gathered was a rich mix of qualitative 
insights about the challenges and hopes of those living and working in the East End of Glasgow.

To attract participants from the East End of Glasgow the project was advertised via social media (including Facebook and Twitter), the GENN (a newspaper for people in the East End of Glasgow), and flyers which were distributed in local supermarkets within Dalmarnock, Shettleston, Parkhead, Baillieston and Easterhouse. Furthermore, all local community councils and East End based housing associations were contacted and asked to distribute information. Community hubs such as the Shandwick Centre in Easterhouse were also visited by the researchers who engaged local people living and working in the area. Participants were asked to keep diaries. We experienced an attrition rate of over $50 \%$ over the course of the research period. Some of those who did not manage to maintain diaries over the period still contributed in the focus groups.

For this project the diaries were researcher-led in that the research team provided guidance based on the background of the project but the content was unstructured and led by participants. The first question asked participants to record their everyday life during June, July, August and September. The second question asked them what was going on in the East End in relation to the CWG, what they saw around them and experienced. The questions were general and open-ended allowing residents to identify the issues that were most important to them. The diaries could be completed online through a blog or in traditional paper diary format as preferred by the participant. The diaries were structure by two main sections. Diaries provide very rich qualitative data and can provide a 'record of an everchanging present.' (Elliot, 1997: 3) This method is particularly useful for 'capturing the everyday' and giving temporal insight to those experiences. (see for example, Kenton, 2010) Contributions to the project varied greatly between daily entries to weekly and monthly entries. The focus groups were unstructured and participant-led, once again allowing residents and those living in the East End to share their own insights and experiences. To protect participants all names were pseudonyms, and participants were given the opportunity to pick these so they could identify themselves in the research.

All online diaries were e-mailed to the researchers each week and were organised and analysed using an online project package. The written diaries were scanned and analysed using manual methods. The analysis of the diaries consisted of a systematic review by the three researchers, which was conducted simultaneously. A small case study was then built around each participant, of which the themes, patterns and understandings emerged inductively. These related to fixity in place, stigma and, which we focus on in this paper, social insecurity.

What emerged was a rich and detailed picture of life in the East End of Glasgow. Those living and working in the area were articulate about the effects of the Games on themselves, those 
around them and their area. The next sections show the link residents made to the local economy of the games, how this linked to changing welfare settlements and the insecurity that the games generated.

\section{The local economy of the Glasgow Commonwealth Games}

Glasgow's East End residents are no strangers to promises of urban regeneration. Rather than being jaded, there was a broad consensus that the Games would benefit the End East. For participants, economic regeneration as a grand ambition and discourse around the Games from Glasgow City Council was supported. Few argued against the promise of increasing jobs in the local area; however, the economic motivations behind top-level decisions were questioned in relation to land and redevelopment. For example:

Well, here we go with Games Legacy - there goes part of Victoria Park on the South side. When I was coaching Rugby, we used those pitches, not the best due to lack of maintenance, but they were ok. You couldn't make it up really, could you? Repeatedly recognised by various Statutory and other Agencies that the city has an Unhealthy population, so how do you combat that? Sell off and reduce the opportunity for sport, especially after an event which has triggered an interest in sporting activity. Is it a Rhod Gilbert sketch? On the other hand, there's a well-recognised situation where, a short period of time after such events, interest wanes and there is less uptake of sport, which means less requirement for facilities and staff to be available, which in turn means less people will take up sport, which means... it's an ever decreasing circle, which requires active support and long-term thinking, and our powers-that- be in this City are good at that aren't they???? Again, I wonder who was consulted about this sell-off..... if anyone, apart from those who'd profit? (David, Diary entry 28 August, 2014)

David is all too aware of the stigma levelled at East End residents with its notoriously poor health record and sees the irony here as the Games related regeneration was prohibiting access to local participation in sports. He expresses concern for the inconsistencies and paradoxes he sees in the delivery of the Games and how incoherent the strategy and thinking was behind it. He sees these inconsistencies as being born of the goal of profit over strategic policy.

At the beginning of the project in particular, our participants were very careful not to be too critical. This seemed to be a conscious decision, and those we talked to pointing out they did not wish to be seen as 'whinging' or 'nit-picking'. They emphasised that they wanted the East End to be welcoming, to be seen as a place with good people and strong communities. This was their chance to promote the area and tackle the negative perceptions placed on it. It was 
clear that there was an obligation on the East End residents to connect to the discourse surrounding the Games that promoted the event as for the 'public good' and for the 'public interest.' (Porter and Gray, 2015)

In the initial focus groups, for example, there were clear tensions between those with a positive and critical perspective (with the researchers often finding they had to intervene). On the positive side of the CWG feedback, people often discussed legacy and local community.

I don't know many people who need a velodrome, but it should impact on community spirit. (Focus Group, 29 May, 2014)

Those who were supportive were also projecting defensive behaviours with statements such as "I refuse to be negative" and "I am sick to death of people mumping" (moaning) being quite common among the supportive individuals in the focus groups. While many participants were initially supportive, subsequent diary entries and focus groups showed a notable shift when residents recorded how they experienced the Games. Optimism waned when benefits did not manifest and disruptions, instead, posed challenges to everyday life.

An example of this is Nathanial, a community worker and member of a local church, who participated in the Games as a volunteer and found this to be a very positive experience that compounded his positive view of the CWGs. He believed in the legacy it was promised to bring and prays for it in his diary entries:

The people I work with are just fantastic, cheerful and friendly and from all kinds of backgrounds. I haven't been able to attend any of the church events, but I believe they are doing very well. I pray that something lasting will come of it. (Nathanial, Diary entry 1 August, 2014)

Only 15 days later, he changes his position before the end through his interactions with others that the Games were meant to impact, which causes him to question the promise of Games related legacy. He witnesses high levels of apathy as the East End is abruptly abandoned.

I tried to raise the subject of the effect of the games, but was met with almost total apathy. The general consensus of opinion seemed to be that the Games, enjoyable though they were, had been relegated to history. (Nathanial, Diary entry, 15 August, 2014)

It should be clear, however, that shifts into critical perceptions for the majority of our participants of the Games events were done cautiously. There was reluctance and some 
fears of being seen as actively disapproving the event that was so singularly promoted through the government and media as the Best Games Ever (Glasgow 2014 Ltd) and something that was for the East End of Glasgow specifically. This is despite the personal disrupted and insecurity it brought to those individuals in the study. For example, as well participants questioning the new uses of their local landscape, there was evidence that those involved in the project were also subject to increased job insecurity due to the Games.

Members of the public and workers in other organisations I work with, have slowly come to realise there are no free services being provided but a charge has creeped in. I and my colleagues have never felt so low, so excluded and sacrificed for the sake of the games. At a time when the whole of Glasgow should be celebrating I face my own private battle with Glasgowlife (an armslength body of Glasgow City Council) as I am sure do my colleagues, to save their own jobs or even just sanity! Both being lost... (Jade, Diary entry 20 June, 2014)

Jade and her co-workers connected the Games with a change from old public welfare service model to privatisation. They were witnessing significant change in their role in the public sector as workers but also as citizens towards consumer citizenship. A consistent theme in the focus groups also included market changes that can take place in an area subject to regeneration.

At the end of the games what happens to the place? Pricing ordinary people out of the market - can't use it, it's too dear. Young ones can't use it - hope this doesn't happen. (Focus Group, 29 May, 2014)

It is important to remember that these events are offered in lieu of long term welfare provision and regenerative interventions to deal with serious socio-economic problems. They provide temporary intervention, improving skills, training and health, creating jobs and community reviving efforts. Furthermore, they are subject to the limitations of area-based regeneration policies as deprivation can only be addressed by looking at wider issues as well as local ones. (Chatterton and Bradley, 2000) This signals the shift to a post-welfare landscape where needs which are buttressed by private services and, most significantly the provision from local voluntary services are playing an increasing role in supporting stigma and fear in certain localities.

\section{The Glasgow Commonwealth Games: increasing insecurity?}

The overt securitisation of the event was seen as unnecessary by residents. Indeed, this was felt to be an affective display to initiate fear, panic and worry. There was an anxiety that was shared before, during and after the CWG had taken place amongst residents. For example: 
Driving through Parkhead Cross on my way to 12 o clock Mass. Lots of activity, Helicopter in the Sky, counted 5 Police cars at the Cross - quite scary really. (Peter, Diary entry 15 June, 2014)

They assume that if you are from Parkhead you take drugs. Target everyone in Parkhead... One morning I got up in the games there were something like 20 police in my street. (Focus Group, 29 August, 2014)

This extended beyond dystopian interpretations to penetrate everyday practices:

My first thoughts are about how much of a disruption that this is going to cause me, all the way up from the Borders there have been sign on the motorway telling us to leave extra time for our journeys and to plan ahead. Once I actually got into my street there was a big sign telling me the street will be closed on 31st July, so I won't get my car in or out at all on that day. This panicked me as I have no idea how I am going to get my son to nursery or myself to work on this day. (Alison, Diary entry 25 July, 2014)

Alison felt marginalised by the processes and a loss of control through the increased regulation and control expressed through Games infrastructure. A further conversation in one of the focus groups revealed the increased difficulties accessing welfare funds, which was specifically linked to the Games. One participant talked about how when he eventually obtained socially rented house he was sleeping on the floor in a sleeping bag. With no other statutory support we had to rely on local voluntary groups and services such as Upkeep which he reported were very good and helped him get a bed which they delivered for free. (Focus Group notes, 29 August, 2014) These examples both highlight the real challenges faced by participants and the impact of the disruption of local services.

What the findings also highlight is the resulting worry and insecurity felt by residents, supporting other recent research that highlights growing insecurity on the back of the 'redistribution of social and societal risk' to disadvantaged individuals and communities in Scotland. (Asenova et al, 2015) Standing (2011: vii) argues that modern society is defined by 'a distinctive bundle of insecurities'. Communities are less linked by work-based identity but rather are unified through job, employment and income insecurity. This gives rise to a "mix of rising anger, anxiety and alienation [that] comprises the inevitable flip side of a society that has made 'flexible' and insecurity cornerstones of the economic system." (Standing, 2011: 24) It is powerful because it offers a mechanism of social control, in which the most insecure internalise stigma, for which they bear responsibility. Similarly to Standing's precariat, people affected by continued insecurity find themselves pathologised further. Overall, "the prospect of persistent insecurity sits uncomfortably with a feeling that it is contrived, not necessary." 
(Standing, 2011: 78) The experiences of the residents in the East End, therefore, highlight that instead of the Games offering the positive impact promised it instead emphasise and added to the insecurities felt by residents in the context of the post-crash UK city.

The importance of access and disruption to local services could not be underestimated. For example, Bettie, who is in her 80 s and is partially sighted, lives close to the Games site. Her world is local, geographically embedded in the Easy End where she has lived her whole life. As such little local changes and events are profoundly meaningful to her world. She reports enjoying walking down the road without lorries, the tar from the Games related road reconstruction had ruined her shoes. Interruptions, not matter how small, can be devastating. Bettie often stays at home, her only outings are to visit the doctor and sometimes she goes dancing. She spends the Games period in hospital after having a fall. Bettie relies on local support and the still, just, publically funded NHS - which she gives thanks to in her last diary entry. She is vulnerable and the Games monolith not only dwarfs her world, its interruption can have a gigantic effect on her localised world and makes the services she requires locally insecure.

The Accord Resource Centre for adults with learning disabilities in the East End was closed to make way for a Games related bus park. The centre offered care management and assessment, specialist health services, day services, respite, supported living and supported employment schemes for over 500 people with learning disabilities. Local women with disabled adult children are at the heart of the centre and rely on it in and the networks that generated around it to get by. The proximity of forms of social reproduction such as family support and childcare is vital particularly in the face of universal welfare cuts, yet it is more also more tenuous. Advocates of the Accord Centre (including previous users of the service) participated in the first focus group where they shared their difficulties since the service had been shut down. In particular, the current transport links and disruptions due to the Games were viewed as key barriers. They also discussed the loss of their social networks and friends since the service had been shut, expressing feelings of exasperation at the process:

People have no idea on what has been proposed and the bullshit around it (Focus Group, 29 May, 2014).

The tenuous and insecure position, as well as the disempowerment of many people living in the East End, was further highlighted through the Commonwealth Games regeneration programme and the violent use of Compulsory Purchase Orders. (Porter and Gray, 2015) The regeneration processes in the East End leaves those in precarious positions in even weaker positions as Glasgow City Council raises and displaces that which is a barrier to the state's brand of market based 'progress'. It frees up land to be put to more profitable use. This was put very clearly in the interviews from the Glasgow Games Monitor (2013): 
When the money went missing, we said, right, where's the money, then? Where did the money go? And they're like [Glasgow City Council], it's not to do with money, its modernisation.

They're the most vulnerable people in Glasgow. And they've just been ripped off. You know what I mean? They're getting ripped off right, left and centre. They were promised a legacy from the 2014 Commonwealth Games, and they're still looking for this legacy.

The findings highlight the insecurity felt by East End residents before, during and after the Commonwealth Games. This was often augmented for vulnerable groups such as older people and those caring and living with disabilities. Although there were temporary benefits felt by participants, these were seen to give way to apathy and disappointment as well as increasing inequalities and barriers. The hope that was outlined before the Games for a positive legacy at the time of finishing this project was on the whole unfulfilled.

\section{Conclusion}

Social pathology and market dogmas define the delivery of the urban social policy strategies discussed here. We argue that the political economy in which the use of large sporting events was premised upon was always too challenging: trickle down logic of capital that wealth created through the games both social and economic will filter down to the local place and residents. The real political economy relates to land value and rent gap and the rescinding of the social contract of welfare. The Commonwealth Games more than anything promoted insecurity over social security in the post welfare post-crash context. We link insecurity to the lack of successful 'legacy' from the event but also to the role the Commonwealth Games play in redefining the welfare settlements attached to certain places. Our finding show a level of chronic insecurity felt by residents before, during and after the event took place. These insecurities were both direct (displacement of services, road closures) and indirect (changes in job roles, nursery provision, housing) to the event itself.

This paper offers innovative approaches in relation to methodology, which is the use of diaries by residents in a disadvantaged locality to record the impacts of large-scale sporting events and associated urban interventions on daily life. The paper is also innovative in locating such events in the wider context of large-scale welfare and social policy interventions with the populations of disadvantaged or impoverished areas. Territorial stigmatisation both legitimates area-targeted policy interventions and paves the way for extensive strategies of urban renewal that attempt to 'recapture' particular areas, transforming them and their inhabitants as ready for private sector investments. The transformation of place, the renaming 
of place and the changing representation of place are all in tune with wider welfare and social policy reforms, not least the attacks on welfare dependency through much more conditional welfare policies and work activation programmes. Remaking and re-representing place is also about transforming populations deemed as problematic, in particular the mendicant. Taken together, urban interventions in the guise of large sporting events (or other kinds of flagship events) are therefore entangled with other strategies that work to turn the dysfunctional welfare subject in to a responsibilised consumer-citizen - and a hard-working consumercitizen at that. 'Regenerated' citizens represent the successful outcome of these strategies, morally renewed as welfare dependency is undermined or eroded. In turn such regenerated citizens come to be seen as distinctive for those remaining mendicants, welfare subjects beyond social and moral regeneration and requiring regulation and control.

Urban regeneration is also about the regeneration of particular targeted social groups. As we have seen, over a period of several years, following a long-period of relative neglect, social and moral regeneration has been aimed at the general population of the East End of Glasgow. Newly regenerated citizens come to be placed in opposition to those deemed to remain problematic but at the same time come to be used as models of successful responsibilisation and of renewed citizens. That this is all taking place during a period in which the most disadvantaged populations of the UK are under direct assault from UK Government policies should remain the focus of our attention. Stigmatisation is part and parcel of such assaults but it is also integral to efforts to remoralise and remake previously abandoned and disadvantaged localities as ready for private sector investment. Much more research is required on the ways in which large events of whatever kinds are seen as vehicles of social renewal, of social re-engineering, in particular localities. There is much talk of legacies and of the benefits of such events - but as we have seen they can also work to exacerbate feelings of insecurity, thereby compounding existing inequalities and existing social injustices.

The Games point to a world of consumption, glamour and excitement that is beyond the reach and financial resources of the vast majority of people in the East End of Glasgow. That it both reflects and points to the existence of such worlds beyond has, as we have highlighted here, only served to increase feelings of insecurity and of exclusion. These both accompany and are the direct consequences of the redistribution of risk and uncertainty to already disadvantaged individuals and localities taking place across the UK today; these are the social costs of welfare reforms and austerity measures which are, in the post welfare urban contexts typified by Glasgow, requiring those with the least and further declining resources to demonstrate 'resilience' and responsibility for the day to day management of low incomes, poor health, unemployment, irregular, low paid and insecure work, deteriorating services and declining social networks. Taken together the individual and social costs are a heightened sense of marginalisation, insecurity and vulnerability. Such is the life for a considerable and growing section of the population across Scotland and the UK today. 


\section{Funding}

Thanks go to the OpenSpace Research Centre, Faculty of Social Sciences, The Open University for funding the project, Beyond Stigma: exploring the experiences of those living in the East End of Glasgow, from which this paper emerges.

\section{Acknowledgement}

Thanks to Parvati Raghuram, Director of the OpenSpace Research Centre for her support and guidance with the research project from which this paper emerges.

\section{References}

Asenova D, McKendrick J, McCann C and Reynolds R (2015) Redistribution of Social and Societal Risk: the Impact on Individuals, their Networks and Communities in Scotland. York: Joseph Rowntree Foundation.

BBC news (2008) Shettleston Man defines city ills, http://news.bbc.co.uk/1/hi/scotland/glasgow_and_west/7227953.stm

Chatterton P and Bradley D (2000) Bringing Britain together? The limitations of areabased regeneration policies in addressing deprivation. Local Economy 15(2): 98-111.

Cochrane A (2007) Understanding Urban Policy: A Critical Approach. Oxford: Blackwell.

Cochrane A, Peck J and Tickell A (1996) Manchester plays games: Exploring the local politics of globalisation. Urban Studies 33(8): 1319-1336.

Collins A (2000) Poverty research and policy for the post-welfare era. Annual Review of Sociology 26: 547-562.

Crossley S and Slater T (2014) Benefits Street: territorial stigmatisation and the realization of a '(tele)vision of divisions. https://values.doc.gold.ac.uk/blog/18/

Donnison D and Middleton A (eds) (1987) Regenerating the Inner City. London: Routledge and Kegan Paul.

Elliott H (1997) The use of diaries in sociological research on health experience. Sociological Research Online. http://www.socresonline.org.uk/2/2/7.html

Friend A and Metcalf A (1981) Slump City: The Politics of Mass Unemployment. London: Pluto Press.

Glasgow 2014 Ltd. (2014) http://www.glasgow2014.com/news/videos/best-gamesever-glasgow-2014

Glasgow Games monitor (2013) Interview with East End carers/Save the Accord. http://gamesmonitor2014.org/interview-with-east-end-carerssave-the-accord

Gray N and Mooney G (2011) Glasgow's New Urban Frontier: 'Civilising' the Population of 'Glasgow East' City 15(1): 4-24. 
Hancock L and Mooney G (2013) 'Welfare ghettos' and the "Broken Society": Territorial stigmatization in the contemporary UK. Housing, Theory and Society 30(1): 46-64.

Hills J (2015) Good Times, Bad Times. Bristol: Policy Press.

Kenton C (2010) Narrating Oneself: Reflections on the Use of Solicited Diaries with Diary Interviews.

http://www.qualitative-research.net/index.php/fqs/article/view/1314/2989

Lansley S and Mack J (2015) Breadline Britain: The Rise of Mass Poverty, London: Oneworld.

Lever W and Moore C (1986) The City in Transition. Oxford: Clarendon.

McCartney G, Hanlon P and Bond L (2012) 'How will the 2014 Commonwealth Games impact on Glasgow's health, and how will we know? Evaluation 19(1): 24-39.

McKendrick J, Mooney G, Dickie J Scott G and Kelly P (2014) Poverty in Scotland 2014: The Independence Referendum and Beyond. London: Child Poverty Action Group.

Mooney G (2004) Cultural policy as urban transformation? Critical reflections on Glasgow, European City of Culture,1990. Local Economy 19(4): 327-340.

Mooney G (2009) The 'Broken Society' election: class hatred and the politics of poverty and place in Glasgow East. Social Policy and Society 8(4): 437-450.

Mooney G and Danson M (1997) Beyond 'culture city': Glasgow as a 'dual city'. In JewsonN and MacGregor S (eds) Transforming Cities. London: Routledge: 73-86.

O’Hara M (2014) Austerity Bites. Bristol: Policy Press.

Paton K, Mooney G and McKee K (2012) Class, citizenship and regeneration: Glasgow and the Commonwealth Games 2014. Antipode 44(4): 1470-1489.

Porter L and Gray N (2015) By any means necessary: Urban regeneration and the 'state of exception' in Glasgow's Commonwealth Games 2014. Antipode 47(2): 380400 .

Reed P (1999) Postscript (1999): the Re-forming of the City. in Reed P (ed) Glasgow. The Forming of the City. Edinburgh: Edinburgh University Press: 223-239.

Rogaly B and Taylor B (2009) Moving Histories of Class and Community. Identity, Place and Belonging in Contemporary England. Basingstoke: Palgrave Macmillan.

Scottish Government (2007) National performance framework. Edinburgh: Scottish Government. http://www.scotland.gov.uk/About/Performance/purposestratobjs 
Slater T (2012) The myth of "Broken Britain": Welfare reform and the production of ignorance', Antipode 46(4): 948-969.

Slater T (2015) Capitalist urbanisation affects your life chances: Exorcising the ghosts of 'neighbourhood effects'. in: Van Ham M, Manley D, MacLennan D, Bailey N and Simpson L (eds) Neighbourhood Effects of Neighbourhood Based Problems? A Policy Context. London: Springer Press.

Standing G (2011) The Precariat: The New Dangerous Class. London: Bloomsbury.

Ward K (2003) Entrepreneurial urbanism, state restructuring and civilizing 'new' East Manchester Area 35(2): 116-127.

Wacquant, L. (2007) Territorial stigmatisation in the age of advanced marginality. Thesis 11 91: 66-77.

Wacquant L (2008) Urban Outcasts. Cambridge: Polity Press.

Wacquant L, Slater T and Pereira V B (2014) Territorial stigmatisation in action. Environment and Planning A 46: 1270-1280.

Wintour P and Elliot L (2014) Osborne moves to cut spending to 1930s levels in dramatic autumn statement. The Guardian December 4. 